\title{
Teacher training students' perception of outdoor activities and their applicability in school centers
}

\author{
Percepción de los estudiantes de Magisterio sobre las actividades en el medio natural \\ y su aplicabilidad en los centros escolares

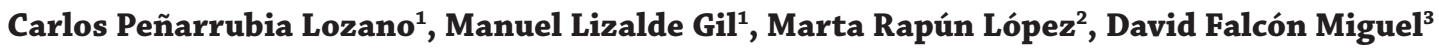 \\ 1 Facultad de Educación. Universidad de Zaragoza. España. \\ 2 Facultad de Ciencias Humanas y de la Educación. Universidad de Zaragoza. España. \\ 3 Facultad de Ciencias de la Salud y del Deporte. Universidad de Zaragoza. España. \\ CORRESPONDENCIA: \\ Carlos Peñarrubia Lozano \\ carlospl@unizar.es \\ CÓMO CITAR EL ARTÍCULO: \\ Peñarrubia-Lozano, C., Lizalde-Gil, M., Rapún-López, M., \& \\ Falcón-Miguel, D. (2021). Teacher training students' percep- \\ tion of outdoor activities and their applicability in school cen- \\ ters. Cultura, Ciencia y Deporte, 16(49), 355-364. http://dx.doi. \\ org/10.12800/ccd.v16i49.1540
}

\begin{abstract}
Teachers' perception of insufficient training is one of the reasons why outdoor activities are not carried out properly in some schools. The aim of this qualitative study was to know the opinion of future teachers about this content. A total of 62 students (34 men and 28 women; $22.74 \pm 1.57$ years) from the Degree in Primary School Education from a Spanish university participated voluntarily. To collect data, practice diaries were employed, completed at the end of the different work contents. A content analysis of the 477 journals delivered through the software NVivo 12-Plus programme was carried out. Previously, a category system defined by two dimensions was established: Firstly, the sensations aroused by the practice of outdoor activities; secondly, their possible replicability in a Primary School classroom. In the first dimension, references to the emotional and social facets dominated. In the second one, the perception of an improvement in professional performance and the intention of replicating it due to its high educational value, as well as the limitations to its applicability in schools were remarkable. It can be concluded that initial training should focus more on finding solutions to the limitations encountered by students.
\end{abstract}

Key words: initial training, perception, usefulness, methodology, limitations.

\section{Resumen}

La percepción de los maestros de una formación insuficiente es una de las razones por las que las actividades en el medio natural no se desarrollan adecuadamente en algunos centros educativos. El objetivo de este estudio cualitativo fue conocer la opinión de los futuros maestros sobre este contenido. Participaron voluntariamente un total de 62 estudiantes (34 hombres, 28 mujeres; $22.74 \pm 1.57$ años) del Grado de Magisterio en Educación Primaria de una universidad española. Para la recogida de datos se utilizaron diarios de prácticas, completados al finalizar los diferentes contenidos de trabajo. Se realizó un análisis de contenido de 477 diarios mediante el programa informático NVivo 12-Plus. Previamente, se estableció un sistema de categorías definido por dos dimensiones: primero, las sensaciones que suscita la práctica de actividades en el medio natural; segundo, su posible replicabilidad en un aula de Educación Primaria. En la primera dimensión, predominaron las referencias sobre las facetas emocional y social. En la segunda, destacaron tanto la percepción de una mejora en el desempeño profesional y la intención de réplica por su alto valor educativo como las limitaciones para su aplicabilidad en la escuela. Se puede concluir que la formación inicial debería incidir más en la búsqueda de soluciones a las limitaciones encontradas por los estudiantes.

Palabras clave: formación inicial, percepción, utilidad, metodología, limitaciones. 


\section{Introduction}

Practicing outdoor activities offers many benefits for the integral development of those performing them (Caballero et al., 2018; Gehris et al., 2012). This fact, along with their training potential, mean that specialists in the Physical Education (PE) subject must make the most of this means while fulfilling overall curricular objectives (Dalmau-Torres, et al., 2020). Students' integral development can be summarized as the correlation that exists among three components: Physical dimension, which is related to possible alterations to the organism; social dimension, linked with relationships among people; mental dimension, related to psychological and emotional factors (TrigoOroza et al., 2016). Although the PE subject currently offers an insufficient timetable, it has the potential to fulfill students integral well-being by including relational, decisional and emotional aspects, what is known according to Parlebas (2001) as the "pedagogy of motor behaviours". In this way, outdoor activities is an excellent driver to help fulfill these objectives.

Bisquerra (2009) defines emotions as reactions to the information received from the environment, influenced by the evaluation that the individual himself gives. In this sense, different works (Dunsmoor et al., 2015; Putwain et al., 2018) have shown that there is a direct relationship between positive emotions and learning. In this way, as future teachers, Primary School Education students must experience outdoor activities so that its subsequent use at school is safe and effective (Sáez-Padilla \& Fuentesal, 2014). Teaching methods are moving toward new methodologies that focus exclusively on students so that their personal, academic and professional training adapts to what the labor world demands (Medina, 2016).

With university students, the European Higher Education Area (EHEA) recommends seeking alternatives to content-centered teaching (De Miguel, 2006), which involves shifting the process priority from what is taught to what students learn (Kop \& Hill, 2008). So it is a matter of moving from those university teaching forms in which students play a passive role to new pedagogic alternatives that favor critical understanding and implication, with students at the center of the teaching-learning process (Castejón Oliva et al., 2015). To achieve this, activities designed by teachers should seek and promote students' reflection, discussion and critical analysis both inside and outside class (Sams \& Bergman, 2013). With this approach, students are not only involved in the process, but also relate previous knowledge and new learnings by integrating theory and practice to achieve global, significant and deep learning (Berbén et al., 2007).

In Spain, the syllabi of University Teacher Training Degrees (regulated by Spanish Royal Decree $1393 / 2007$, of October 29) include basic, compulsory and optional subjects, which enables a curricular specialism to be obtained as part of the degree. Therefore, some universities' Teacher Training syllabi include an optional about subject outdoor activities with 6 ECTS credits as part of the PE specialism. However, the initial training offered to future teachers is considered insufficient, and teachers have to bridge this training gap by either attending courses to train in these contents or relying on their own experience (Navarro et al., 2015). Cañadas et al. (2019) state that lack of outdoor activities training is more relevant for university teachers. In line with this, Arribas (2008) point out how university institutions' limitations act as a structural barrier. University teachers state that having too many students registered for subjects prevents certain practices from being properly done.

In line with performance in the PE area for the Primary Education stage, nowadays Organic Law on Improving Education Quality (LOMCE, 2013), specified by Royal Decree 126/2014, sets out five different main situations and indicates the need for them all to be present in a varied and balanced manner. Despite the many benefits associated with performing these activities, practicing the block of outdoor activities contents is limited compared to other curricular contents for many different reasons; e.g., the risk incurred by these activities, lack of PE teacher training in outdoor activities, the need to rely on specific materials and premises, available class time (Peñarrubia et al., 2016) or no specific training in these contents (Hovey et al., 2020).

Therefore, the objective of this study was to analyze the perception held by future teachers of the initial outdoor activities training they receive and its suitability for their future practical work as teachers.

\section{Method}

\section{Participants}

This study was conducted as part of the Degree in Primary School Education from a Spanish university during academic year 2019/20. The participants were 62 year-4 students registered for the optional subject outdoor activities of this degree, of whom 34 were male $(54.84 \%)$ and 28 were female $(45.16 \%)$. Their mean age was $22.74 \pm 1.57$ years. These students 
voluntarily participated by signing informed consent. Likewise, this research obtained the ethical approval of the Ethical Committee of the University of authors.

\section{Instruments}

To collect data, practice diaries were employed that had been completed by the students when they finished outdoor activities sessions. The structure of the diaries had two differents parts (Figure 1). Firstly, there was a contextualization in which the dates, work contents and activities carried out had to be indicated. Secondly, the participants had to respond in an open way, without a defined extension, to two points of interest: On the one hand, how they perceive outdoor activities as people practicing them. The four dimensions defined by Parlebas (2001) for motor behaviour -cognitive, social, physical and emotional-, could serve as examples for their reflections. On the other hand, students had to explain how relevant this training can be for their future work.

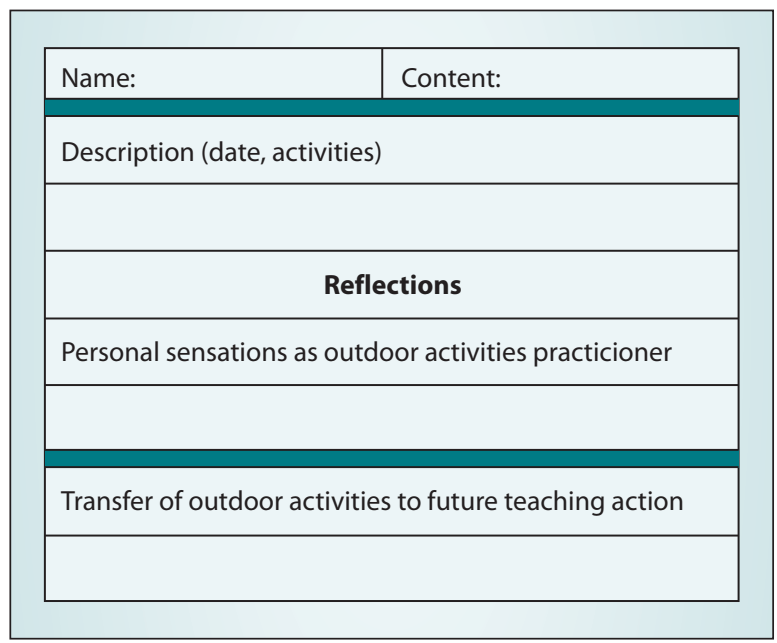

Figure 1. Practice diary.

\section{Procedure}

The participants in this study had to make notes in their practices diary and hand it in after a maximum time of 1 week once the corresponding session had ended. Filling in and delivering diaries formed part of the subject's continuous evaluation. This allowed the depth of the descriptions to be exclusively evaluated to obtain an Apt or Not Apt classification with the corresponding weighting in the final mark. This allowed us to bear in mind the students' views, provided they offered arguments to justify their views without considering agreeing or disagreeing with how the tasks included in the practical sessions were contemplated.
Analysis

The qualitative analysis of diaries was performed according to the phases proposed by Bardin (2002): Preanalysis, exploring the material, processing and interpreting data. The first pre-analysis phase consists in devising the categories system. To this end, all the diaries were read to complete the aforementioned list of indicators (Table 1). This limited the study object to two dimensions obtained from a deductive and adaptive process, adapted from Canales-Lacruz and Ponzán-Frisa (2016). Dimension 1. Integral perspective refers to the evaluation made by the students about their own experience from personally experiencing sessions. The analysis criterion was based on the capacities contributing to someone's overall development (Bisquerra, 2009; Parlebas, 2001): Physical, cognitive, emotional and relational capacities; Dimension 2. Using and accepting the learning objects, seeks to find the relevance of the developed contents and the methodology worked with to face their future application in class. The formulation of this second dimension is based on the Theory of Reasoned Action (Ajzen \& Fishbein, 1980), the Self-Determination and Facilitation of Instrinsic Motivation Theories (Ryan \& Deci, 2000) and the Technology Acceptance Model (TAM) perspective by Davis et al. (1989). The TAM has been widely accepted in recent years to be used to study new learning contexts and objects of information and communication technologies (ICT), e-learning methodologies, WebCT, portfolios, etc. (Arteaga \& Duarte-Hueros, A., 2010; Fernández Robles, 2016; Torres Alberro et al., 2017).

Once the two main dimensions were known, an analysis was carried out in accordance with the following definitions associated with the categories below:

1.1. Physical: Bioenergy capacities, linked directly with performing physical activity. Actions performed to develop one's physical condition, and the basic and specific motor skills typical of each sport (covering a distance in the shortest possible time, throwing an object accurately over a distance, etc.).

1.2. Cognitive: When intellectual development occurs. It includes reasoning capacities that imply certain tasks like knowing, understanding, reflecting, analyzing, comparing or assessing.

1.3. Emotional: A personal balance understood as the pyscho-affective relation someone maintains with oneself. It includes the self-control capacity (managing emotions), as well as effort and personal growth.

1.4. Relational: A set of relationships established among individuals. They are normative- and/or ethical-like aspects that derive from life in society. 
Table 1. Categories system.

\begin{tabular}{|c|c|c|}
\hline Dimension & Category & Indicators \\
\hline \multirow[t]{11}{*}{ 1. Integral perspective } & 1.1. Physical & 1.1.1. Conditional capacities \\
\hline & & 1.1.2. Coordinative capacities \\
\hline & & 1.1.3. General, basic and specific motor skills \\
\hline & 1.2. Cognitive & 1.2.1. Knowledge \\
\hline & & 1.2.2. Reflection \\
\hline & 1.3. Emotional & 1.3.1. Identifiying own emotions and those of others \\
\hline & & 1.3.2. Self-control and handling emotions \\
\hline & & 1.3.3. Emotional autonomy \\
\hline & 1.4. Relational & 1.4.1. Respecting others and accepting differences \\
\hline & & 1.4.2. Accepting and keeping to rules \\
\hline & & 1.4.3. Cooperative and oppositional relationships \\
\hline \multirow{7}{*}{$\begin{array}{l}\text { 2. Using and accepting } \\
\text { learning objects }\end{array}$} & 2.1. Perceived enjoyment & 2.1.1. Enjoying or liking these contents \\
\hline & 2.2. Perceived usefulness & 2.2.1. Perceiving technical quality \\
\hline & & 2.2.2. Encouraging autonomy \\
\hline & & 2.2.3. Improving professional performance \\
\hline & 2.3. Perceiving easy use & 2.3.1. Facilitators \\
\hline & & 2.3.2. Limiters \\
\hline & 2.4. Attitude about use & 2.4.1. Intention to replicate \\
\hline
\end{tabular}

2.1. Perceived enjoyment: This entails feeling pleasure when doing something, which is intrinsic motivation. The activity itself produces enjoyment, and not the expectation of obtaining prizes or social acknowledgment/approval.

2.2. Perceived usefulness: The belief someone has that using a given system offers improvement.

2.3. Perceived easy use: Defined as someone believing that using a system is effortless.

2.4. Attitude about use: Having reflected on the categories of enjoyment, usefulness and easy use, the students could assess their intention of repeating the contents and activities, or not, in the future with their pupils.

The indicators found in Table 1 are the last specification level at which the different response typologies in the content analysis were obtained. All the categories are in accordance with the criteria defined by Heineman (2003) about exhaustiveness and exclusivity.

Next a pilot test was run with a small sample that was randomly selected $(n=96 ; 20.13 \%)$ to analyze the reliability between two independent analysts. The obtained Kappa Index was $k=.84$, which reflects a suitable level of agreement. In the second exploring the material phase, all the diaries were coded according to the previously defined indicators. The QSR-Nvivo 12-Plus software was employed to process and interpret the results, which offered a first descriptive analysis of the number of coded references. Finally, an interpretative analysis was run in accordance with the study objectives. It was supported by the testimonies offered by the participants.

\section{Results}

\section{Descriptive analysis}

The participants' response rate was high $(85.48 \%$ deliveries of a total of 558 possible deliveries). They all handed in at least one diary, which meant that $100 \%$ of the students participated throughout the subject. A higher mean number of deliveries was obtained for females in all the modules and for the complete set (90.48\% vs. $81.37 \%)$.

The content analysis of the 477 student diaries (Table 2) reflected 7728 codings, with 20846 lines. Of the 3299 (42.69\%) references coded in Dimension 1. Integral perspective, the category that stood out was 1.3. Emotional, with $35.13 \%$ (Figure 2). In this dimension, indicator 1.3.1. Identifying own emotions and those of others appeared more frequently with $89.21 \%$ of the codings. The most represented indicators for the categories 1.4. Relational and 1.1. Physical were, respectively: 1.4.3. Cooperative and oppositional relationships (90.98\%) and 1.1.1. Conditional capacities (94.18\%). Dimension 2. Using and accepting learning objects gave 4429 codings (57.31\%). Perceived usefulness appeared as the most outstanding category (41.79\%), with indicators 2.2 .3 . Improving professional performance $(58.18 \%)$ and 2.2.1. Perceiving technical quality (39.28\%) as the most important ones. In category 2.3. Perceiving easy use $(35.74 \%)$, remarks about facilitators represented $30.39 \%$, vs. $69.61 \%$ for aspects that could limit 
Table 2. Relation between performed contents and number of delivered diaries.

\begin{tabular}{|c|c|c|c|c|c|c|c|}
\hline Content & N sesions & $\mathrm{N}$ men diaries & $\%$ men diaries & $\mathrm{N}$ women diaries & $\%$ women diaries & $\mathrm{N}$ total diaries & $\%$ total diaries \\
\hline Orienteering 1 & 2 & 31 & 91.18 & 26 & 92.86 & 57 & 91.94 \\
\hline МTB & 3 & 31 & 91.18 & 27 & 96.43 & 58 & 93.55 \\
\hline Climbing & 2 & 33 & 97.06 & 28 & 100.00 & 61 & 98.39 \\
\hline Skating & 2 & 33 & 97.06 & 28 & 100.00 & 61 & 98.39 \\
\hline Obstacle race & 1 & 30 & 88.24 & 26 & 92.86 & 56 & 90.32 \\
\hline Hiking & 2 & 30 & 88.24 & 28 & 100.00 & 58 & 93.55 \\
\hline Orienteering2 & 1 & 29 & 85.29 & 24 & 85.71 & 53 & 85.48 \\
\hline Camping & 1 & 26 & 76.47 & 28 & 100.00 & 54 & 87.10 \\
\hline Skiing & 3 & 6 & 17.65 & 13 & 46.43 & 19 & 30.65 \\
\hline Total & 16 & 249 & 81.37 & 228 & 90.48 & 477 & 85.48 \\
\hline
\end{tabular}

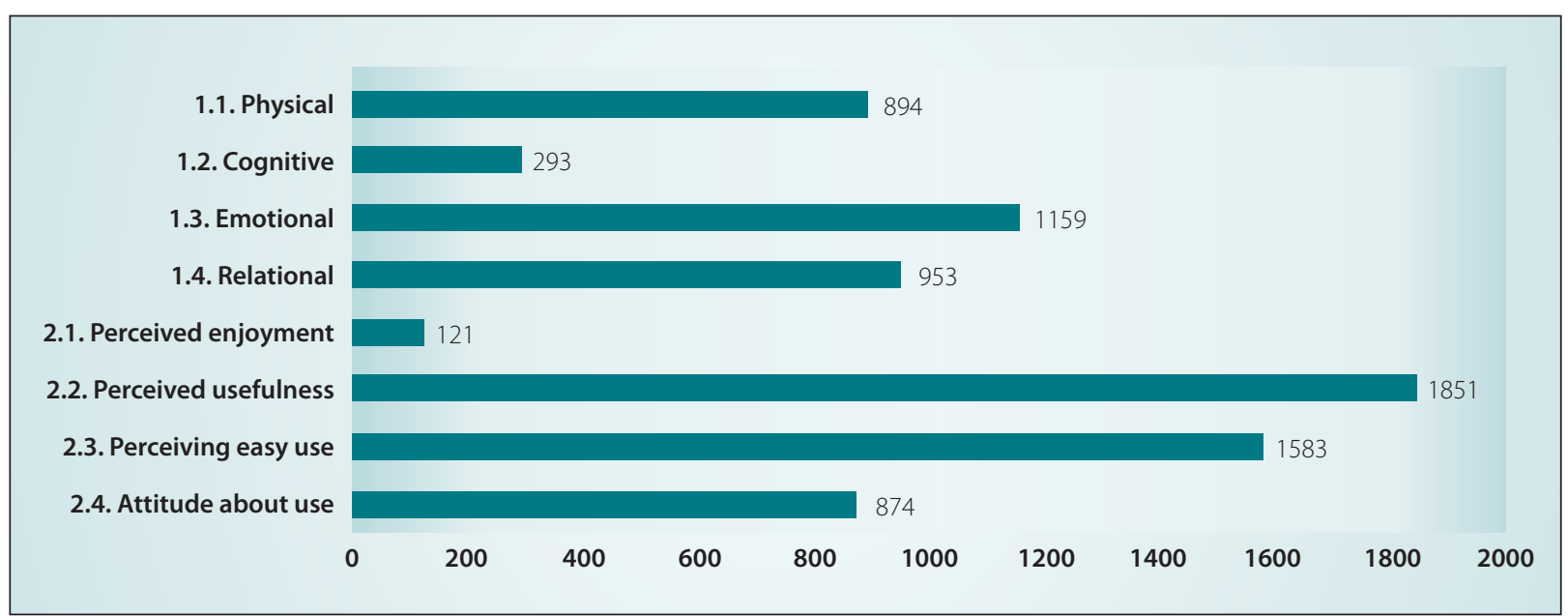

Figure 2. Number of codings per category.

putting outdoor activities into practice in education centers. This was followed far behind by Attitude about use with only one indicator that referred to intention to replicate activities (19.73\%). Finally, very few participants made remarks about perceiving enjoyment (2.73\%).

This first descriptive analysis helped to understand the points of interest that the students included in their diaries. An interpretative analysis was performed. To reinforce their reflections, some texts were taken directly from diaries. The authors' initials do not match the participants' real names to ensure they remain anonymous.

\section{Interpretative analysis}

\section{Dimension 1. Integral perspective. Reflections as outdoor activities practicioners}

The students considered that speed and resistance were the two conditional capacities that were most developed during sessions. For example, BE states that Physically speaking, it's a simple way to work physical activity by practicing speed and resistance (as long distances are covered in the second session task) (Orienteering 1). However, by employing Borg's subjective scale of perceived exertion, with modified scores from 1 to 10, values between 2 and 4 points were obtained for intensity. SH stated that I think I'd give about 2-3 points for the physical experience using Borg's subjective scale of perceived exertion (Skating). Only the steeplechase and the bicycle ride reached 6 and 8 points, respectively. The participants indicated not being used to the task as the main reason for these scores. Finally, their reflections revealed that they distinguished two evaluations during the sessions spent on climbing content, with high intensity when climbing, but a lower evaluation for the whole session.

The most frequently noted emotion in indicator 1.3.1. Identifying own emotions and those of others is fear, especially for having to face unknown activities (particularly for climbing), as JU highlighted:

In the psychological experience, with this module I began to feel more afraid, afraid of not being able to react to possibly make a mistake while explaining 
on the climbing wall, especially when opening the way before my classmates as I was afraid of making a mistake. (Climbing).

Embarrassment from being exposed before the class group or feeling afraid of making mistakes in team contests were also recurring emotions. TH says:

Some of the challenges we were presented with let you put your fears to one side, which helped me to open up to the classmates I knew less, and to not feel ashamed of being in public with other people we did not know. (Hiking).

The overall remarks made in indicator 1.4.3. Cooperative and oppositional relationships positively evaluated the suitability of the cooperative learning with which sessions were organized. Not only did it encourage teamwork, but the students also stressed that this methodology helped them to overcome the initial fears they mentioned in the previous indicator: In social terms, the cooperative games considered to be challenges with inevitably combined goals. This encouraged us to work as a team, to think, to try various options and to find the best one (NM, MTB).

Moreover, we verified the feelings that came over when evaluating the methodological approach based on the competition included in some work contents. Although they were well evaluated as regards their motivational aspect, some remarks were made about their excesss competitiveness in some cases as opposed to the learning purpose of the session.

Nonetheless, I was struck by the competitiveness involved, which was sometimes ignored. As I told lots of my classmates that I can't skate, they decided to choose more competent people for their teams rather than give priority to friendship and empathy. (QH, Skating).

When looking at the less relevant indicators in Dimension 1. Integral perspective, we found that the participants reflected on the theoretical and practical knowledge they had learned, and having developed coordination capacities, particularly during the skating sessions and in the obstacle race. Several participants stressed the need to stick to the rules, especially during those sessions in which they could share spaces with other participants. For instance, during the urban hiking session or the developed orienteering sessions in public parks, as NN pointed out: As we showed a lot of respect to everyone outside and the different places we moved around in, the session was a great success (Orienteering 2).
The participants also included remarks about the seriousness and honesty they applied while performing contest tasks, like the obstacle race: All the members of the different groups paid considerable attention to the indications and tried to make as much effort as possible during the test no matter what obstacles were used to seek approval and do the test well (NC, Obstacle race).

Dimension 2. Using and accepting learning objects. Reflections about outdoors applicability in a Primary School classroom

The most repeated reflections made on indicator 2.2.1. Perceiving technical quality centered on the methodology followed, particulary regarding the overall view it offered: I thought that the option of using the school playground was interesting to work on whenever the center doesn't let us go to some nearby outdoor places for a given circumstance (SM, MTB).

Positive evaluations about using technologies as a resource were also included to favor learning:

As observations, I'd like to point out how at ease I felt during the session. The main characteristic I stress is that I liked the idea of using panels with $\mathrm{QR}$ codes, which led to an explanatory video of what to do in each task. It was easy to understand and hardly any time was lost. (SQ, Obstacle race).

For indicator 2.2.3. Improving professional performance, two ideas were stressed. The first was about knowledge of new resourses and possibilities of developing the contents that the students had not previously considered. The second idea was about the possibility that these contents offer for stimulating interdisciplinary work in the classroom with boys and girls in Primary Education. ICT were mentioned again as an ideal complement for this.

Finally I'd say that, as teachers, we'll have to be willing to adapt the activities so they can be performed, like urban hiking. It would always be a good option to employ tools like plickers because we will be working in a novel way, which will attract children, and will allow us to work contents more easily. (NN, Hiking).

The need for more complete training to employ these contents as safely as possible was stressed. Initial training seemed insufficient, but stirred concerns among students to contemplate permanent training. IN states that I realized that I didn't have enough information to teach orientation classes and, to do 
so, I must seek information and make a note of everything I received from the teacher (Orienteering 1 ).

The students stressed that the natural resources and premises employed to hold sessions both on and off the university campus are the main elements of the facilitators that can help them to transfer these contents and activities to their future professional work. Regarding the climbing content, FH states: These possibilities could consist in adapting them to other places, like wall bars which, despite not being the same thing, might be a useful tool when teaching children abseiling and climbing.

Once again, special mention was made about including computer applications, which allow these contents to be contemplated in an interdisciplinary manner. SH also wished to point out for climbing that: No doubt another very important facilitator is all the organized games, particularly those done with the projector because they let the participants do interdisciplinary work with other areas like Maths or English.

Both materials and premises were considered a main limitation source if they are not available in the future. Other reasons were added, like not knowing activities and the center's management or fathers/ mothers/guardians being afraid, which might prevent them from participating. In the specific case of skiing, the economic factor came over as the main limitation factor, and referred to both the sport itself (access fees, hiring material) and the complementary management of travelling and accommodation: There's not just the material used, but also transport, accommodation if it's practiced on several days running and access fees, which aren't cheap. All this often makes ski-ing an expensive sport (SH, Skiing).

Most of the reflections included possible alternatives or solutions if these problems arose. Indeed, the participants considered that adapting spaces and collaborating with other education centers to create a common materials bank might be more realistic possibilities.

Generally speaking, the students indicated their willingness to use these contents in future programs when they exercise in Primary Education rooms. Two types of evaluations were identified in indicator 2.4.1. Intention to replicate. The first involved those who explained their idea to carry out the practices exactly as they had been presented in the subject, but adapting intensity to pupils' ages.

I feel that this practice can be adapted and made suitable as such to be performed at school because it sets up practical themes that everyone must master before going camping. It's also suitable for carrying it out in a Primary Education classes because these pupils will go camping and live this experience. So they must have basic knowledge about the theme. (TH, Camping).

The second type of evaluation included possible aspects to bear in mind when repeating the task, with highlighted proposals made to modify it. For example, the proposal by SB for the Orienteering 2 content: It's perfect for working transversally, and can be done in the future if helped by other teachers, who might be teachers from other classes, tutors, the teachers of the next class, etc.

Category 2.1. Perceiving enjoyment was defined by only one indicator, which included enjoyment that the intrinsically presented contents entailed for the participants. Its presence was taken into account less than other analyzed units. However, the reported codings showed that references were made to all contents, especially with climbing, MTB and the obstacle race. The participants pointed out the novelty involved and coming into direct contact with the natural environment as a practice scenario as the main reasons for perceiving enjoyment.

\section{Discussion}

One of the main purposes of training future teaching professionals is to acquire the competences they need to improve their teaching efficiency (Choi et al., 2020; Del Valle et al., 2015). For several authors, teaching efficiency in the PE area is closely related to the physical literacy (PL) concept (Conlin, 2013; Flemons et al., 2018; McLennan \& Thompson, 2015). As Whitehead et al. (2018) define it, someone with $\mathrm{PL}$ is skilful and motivated to plan and participate in physical activities. Therefore, improving PL in outdoor acitivities must be future teachers' priority in order to ensure its implementation in their teaching action.

For outdoor activities, there are many signs showing that PE teachers' training for teaching this content in Primary, Secondary and Higher Education is insufficient (Cañadas et al., 2019; Granero, 2014; Hurtado et al., 2020; Navarro, et al., 2015; Sáez-Padilla et al., 2017). The present experience was done to analyze how 62 future teachers perceived the outdoor activities training they receive and its relevance for their future work as teachers using 477 practice diaries.

Outdoor activities offers a huge educational potential because it takes place in nature and was conceived as an ideal classroom for students' integral development (Pérez-Brunicardi et al., 2017). By taking 
integral development as the sum of physical, cognitive, emotional and social components, the present study reveals how the last two components more strongly affected such activities, which coincides with other studies (Caballero, 2014; Prouty et al., 2007; Santos \& Martínez, 2011). The emotional category came over as the most representative, and fear and embarrassment were stressed more. These results reinforce the idea that outdoor activities provokes a series of particular emotions from feeling uncertainty and freedom, which impact students' behavior and relationships (Caballero, 2015; Cornell, 2018). Our students also indicated that these negative feelings fade or disappear thanks to teamwork and the social relations established while performing the different activities. This reflection coincides with the study by Trigo-Oroza et al. (2016), which concludes that outdoor activities contrinbutes to students' integral development, mostly in mental and social terms, and students' motivation increased after ending the intervention program they participated in.

Regarding the physical part of integral training, the majority of students gave scores of between 2 and 4 on Borg's scale (modified to values from 1 to 10). This would determine that exertion intensity was between mild and somewhat strenuous. Such intensity is due to the methodology followed during sessions as the students were training to be future teachers, which implies that the time spent practicing on PE was combined with explanations and reflections.

The cognitive component appeared less in the diaries. This might be because our students perceived the training they received as a useful tool for their future as teachers. Along the same line, how they perceived enjoyment from the entertainment they participated in with these contents did not often appear in the diaries, which may be due to the context in which they lived these experiences. Our participants were Teacher Training Degree students who were very keen on learning, considering the resources offered to apply outdoor activities at school, seeing possible problems and how to solve them, and all this while being supervised by a university teacher. The way these activities were designed focuses more on the didactic perspective toward teaching than the intrinsic perspective of practicing outdoor activities.

Our students pointed out the different limitations they encountered to put outdoor activities into practice in their future teaching work. The main limitation was lack of available materials, which is also one of the main limitations found in previous literature works (Dalmau-Torres et al., 2020). In line with this lack of material resources, it is necessary to point out other limitations as regards available premises or adapted spaces, and even difficulties accessing nearby natural environments given the location of education centers (Rickinson et al., 2012).

Another limitation they pointed out was lack of knowledge of activities, and the center's management and parents being afraid of the risk that performing outdoor activities incurs, which coincides with Llandres and Sáez Rodríguez (2012). To this fear, these authors added a problem or gap in the legislation as to who is held responsible in the event of an accident.

Economic resources were also indicated as limiting elements for practicing outdoor activities. Falo et al. (2020) defined three kinds of limitation: What such activities cost (insurance, materials, specialized monitors, etc.); students' own socio-economic status; the need to travel to a suitable practice area. Regarding this last point, our students clearly pointed out the cost of skiing as a genuine problem for this sport to be practiced by education centers. This economic limitation for skiing is surprising and contradictory in a region like Aragón where snow-related activities are a driver of economy. However, this region does not encourage practicing snow sports with schoolchildren by lowering prices for them to go to ski runs, and even did away with aid for schools and institutes after the last economic crisis that began in 2008.

Despite the relevant and suitable reflections that the students made in their diaries about how they perceived limiters of applying outdoor activities at school, we stress other problems found in the literature, which may be due to their lack of experience in the management and teaching of such activities. They did not believe that their training as part of the Teacher Training Degree syllabus was limited or insufficient, which other authors have also pointed out (Llandres \& Sáez Rodríguez 2012). Nor did they evaluate the difficulties that they may encounter in the future with students with specific education needs, such as accidental lesions or sporadic/chronic diseases, or students with some motor, sensorial, psychic or social disability (Peñarrubia et al., 2016). Our students did not reasonably identify some other limiting factors, such as institutions' support (Chubb \& Moe; 2011; Dalmau-Torres et al., 2020; Sáez-Padilla et al., 2011) and how schools are run. Granero et al. (2010) indicated the problems of being able to schedule outdoor activities as part of the PE subject owing to center's unflexible timetables, and outdoor activities possibly interfering with other scheduled subjects.

Regarding how they perceived easy use, the students stressed, from the experiences they gained from participating, the need to adapt available spaces and materials, such as using wall bars and other 
elements frequently found in many education centers. Once again, this coincided with authors like BaenaExtremera et al. (2013).

For the perceived technical quality of the experiences they lived, our students pointed out two relevant elements; first the employed methodology (comprehensive, participative and cooperative); second using ICT as the ideal complement for motivation and participating in such activities (Gallego-Lema et al., 2017). The relevance of using ICT was also pointed out as an enabling element to carry out interdisciplinary work in class, which is one of the main educational benefits related to performing outdoor activities (Tejada \& Sáez-Padilla, 2009).

As for perceived usefulness for their future professional performance, once again our students reflected on using ICT and added another important element about these contents stimulating interdisciplinary work in class. Several authors have also employed this argument to indicate the opportunity that outdoor activities offers to work on environmental education (Sáez-Padilla et al., 2011). So our students expressed their attitude about performing outdoor activities and their intention to replicate it at school after suitably and necessarily adapting them to schoolchildren's characteristics.

\section{Conclusions}

Our students positively assessed their experience and experimentation with the contents as a necessary process for their learning. Participating in teaching sessions helped them to understand the volume of preparation work that must be done before considering such activities. Likewise, they indicated the need for continuous training to reinforce and recycle their learning.

The held sessions involved mild physical intensity, which were changing sessions from the psycological point of view. Positive emotions predominated, although others like fear and embarrassment appeared, especially in the abseiling and climbing tasks. They generally overcame any negative emotions through group work by overcoming initial embarrassment before the classmates they did not know well, the fear of preconceiving an activity as hazardous or motortype challenges.

As to the employed methodology, using ICT came over as the ideal complement to increase motiviation and participation in such activities. The students also stressed the possibilities that working in the natural environment offered from a transversal perspective, along with other PE contents, or interdisciplinary work with other curricular subject matters.

The main limitations that our students found were the possible refusal of not leaving the education center and the need to use specific materials, which they believed could be solved by considering alternatives to perform initiation tasks adapted to schoolchildren's ages inside education centers. These conclusions highlight that initial training should focus more on finding solutions to the limitations of outdoor activities in order to be carried out in school.

\section{REFERENCES}

Aizen, I., \& Fishbeim, M. (1980). Undestanding attitudes and predicting social behavior. Englewood Cliffs, NJ: Prentice-Hall.

Arribas, H. (2008). El pensamiento y la biografía del profesorado de Actividad Física en el Medio Natural: Un estudio multicaso en la formación universitaria orientado a la comprensión de modelos formativos (Tesis doctoral). Universidad de Valladolid, Valladolid.

Arteaga, R, \& Duarte-Hueros, A. (2010). Motivational Factors that influence the acceptance of Moodle using TAM. Computers in Human Behavior, 26(6), 1632-1640. doi:10.1016/j.chb.2010.06.011.

Baena-Extremera, A., Serrano, J. M., Fernández, R., \& Fuentesal, J. (2013). Adapting new Adventure Sports to School Physical Education: Via Ferratas. Apunts. Educación Física y Deportes, 114, 3644. doi:10.5672/apunts.2014-0983.es.(2013/4).114.03.

Bardin, L. (2002). Análisis de contenido. Madrid: Akal.

Berbén, A. B. G., Pichardo, M. C., \& de la Fuente, J. (2007). Relationships between teaching preferences and undergraduates' learning approaches. Journal for the Study of Education and Development, 30(4), 537-550. doi:10.1174/021037007782334319.

Bisquerra, R. (2009). Psicopedagogía de las emociones. Madrid: Síntesis.

Caballero, P. J. (2014). El desarrollo positivo y las actividades físicas en el medio natural. Tándem, 45, 42-52.

Caballero, P. J. (2015). Diseño, implementación y evaluación de un programa de actividades en la naturaleza para promover la responsabilidad personal y social en alumnos de formación profesional. Cuadernos de Psicología del Deporte, 15(2), 179-194.

Caballero, P. J., Hernández-Hernández, E., \& Reina, M. (2018). Analysis of Universal Factors of Physical Activities in Natural Environment/ Adventure Physical Activities in Nature (Outdoor Activities): Preliminary Research. Espiral. Cuadernos del profesorado, 11(22), 61-68.

Canales-Lacruz, I., \& Ponzán Frisa, A. (2016). Motivos de satisfacción e insatisfacción del alumnado de educación física en situaciones motrices de béisbol. Revista de educación física, 34(3), 1-8.

Cañadas, L., Castejón, J., \& Santos-Pastor, M. L. (2019). Teaching competences in physical education teacher initial training. Retos, 35, 284-288.

Castejón Oliva, F. J., Santos Pastor, M. L., \& Palacios Picos, D. (2015). Cuestionario sobre metodología y evaluación en formación inicial en educación física. Revista internacional de Medicina y Ciencias de la Actividad Física y el Deporte, 15(58), 245-267. doi:10.15366/ rimcafd2015.58.004

Choi, S. M., Sum, K. W. R., Wallhead, T., Ha, S. C. A., Sit, H. P. C., Shy, D. Y., \& Wei, F. M. (2020). Pre-service physical education teachers' perceived physical literacy and teaching efficacy. Journal of Teaching in Physical Education, 1, 1-11. doi:10.1123/jtpe.2019-0076.

Chubb, J. E., \& Moe, T. M. (2011). Politics, markets, and America's schools. Whasington, D.C. (U.S.): Brookings Institution Press. 
Conlin, G. (2013). Teacher pupil relationships. International Council of Sport Science and Physical Education Bulletin, 65, 379-384.

Cornell, J. (2018). Compartir la naturaleza. Sevilla: Ediciones La Traviesa.

Dalmau-Torres, J. M., Jiménez, R., Gómez, N., \& Gargallo, E. (2020). Diagnosis of the treatment of physical activities in the natural environment within Physical Education. Retos, 37, 460-464.

Davis, F. D., Bagozzi, R. P., \& Warshaw, P. R. (1989). User acceptance of computer technology: A comparison of two theoretical models. Management Science, 35, 982-1003. doi:10.1287/mnsc.35.8.982.

Del Valle, S.; De la Vega, R., \& Rodríguez, M. (2015). Percepción de las competencias profesionales del docente de educación física en primaria y secundaria. Revista internacional de Medicina y Ciencias de la Actividad Física y el Deporte, 15(59), 507-526. doi:10.15366/ rimcafd2015.59.007.

De Miguel, M. (2006). Modalidades de enseñanza centradas en el desarrollo de competencias. Orientaciones para el profesorado universitario ante el espacio europeo de educación superior. Madrid: Alianza.

Dunsmoor J., Murty V., Davachi L., \& Phelps E. (2015). Emotional learning selectively and retroactively strengthens memories for related events. Nature, 520, 345-348. doi:10.1038/nature14106.

Falo, M., Sanz, M., \& Peñarrubia, C. (2020). Collaborative work and Physical Education: A climbing didactic proposal in Primary Education. Retos, 37, 706-712.

Fenández Robles, B. (2016). Factors that influence the use and acceptance of learning objects of augmented reality in university studies of Primary Education. Edmetic, 6(1), 203-220. doi:10.21071/ edmetic.v6i1.5815.

Flemons, M., Diffey, F., \& Cunliffe, D. (2018). The role of PETE in developing and sustaining physical literacy informed practitioners. Journal of Teaching in Physical Education, 37(3), 299-307. doi:10.1123/ jtpe.2018-0128.

Gallego-Lema, V., Muñoz-Cristóbal, J. A., Arribas-Cubero, H. F., \& RuviaAvi, B. (2017). Orienteering in the natural environment: Ubiquitous learning through the use of technology. Movimento, 23(2), 755-770. doi:10.22456/1982-8918.71682.

Gehris, J., Myers, E., \& Whitaker, R. (2012). Physical activity levels during adventure-physical education lessons. European Physical Education Review, 18, 245-257. doi:10.1177/1356336X12440365.

Granero, A. (2014). Actividades en el medio natural, aula y formación del profesorado. Tándem, 45, 8-13.

Granero, A., Baena, A., \& Martínez, M. (2010). Contenidos desarrolla dos mediante las actividades en el medio natural de las clases de Educación Física en Secundaria Obligatoria. Ágora para la educación física y el deporte, 12(3), 273-288.

Heinemann, K. (2003). Introducción a la metodología de la investigación empírica. Barcelona: Paidotribo.

Hovey, K., Niland, D., \& Foley, J. T. (2020). The Impact of Participation in an Outdoor Education Program on Physical Education Teacher Education Student Self-Efficacy to Teach Outdoor Education. Journal of Teaching in Physical Education, 39, 18-27. doi:10.1123/jtpe.2018-0288.

Hurtado, M., Sanabrias, D., Sánchez, M, \& Cachón, J. (2020). Actividades Físicas en el Medio Natural. Incidencia en la formación del Profesorado y su enseñanza en la ESO. Sportis, 6(1), 18-42. doi:10.17979/ sportis.2020.6.1.5769

Kop, R., \& Hill, A. (2008). Connectivism: Learning theory of the future or vestige of the past? The International Review of Research in Open and Distributed Learning, 9(3), 1-13. doi:10.19173/irrodl.v9i3.523.

Llandres, A., \& Sáez Rodríguez, G. (2012). Situación educativa actual de las actividades físicas en el medio natural: Planteamientos y soluciones. Revista Internacional de Deportes Colectivos, 13, 14-31.

Ley Orgánica 8/2013, de 9 de diciembre, para la mejora de la calidad educativa.

McLennan, N., \& Thompson, J. (2015). Quality physical education: Guidelines for policy makers. Paris, France: United Nations Educational, Scientific and Cultural Organization.
Medina, J. L. (2016). La docencia universitaria mediante el enfoque del aula invertida. Barcelona: Octaedro.

Navarro, R., Arufe, V., \& Sancosmed, E. (2015). The nature activities in physical education. Formation and attitude of teachers in Elementary School. Retos, 27, 122-126.

Parlebas, P. (2001). Juegos, deporte y sociedad. Léxico de praxiología motriz. Barcelona: Paidotribo.

Peñarrubia, C., Guillén, R., \& Lapetra, S. (2016). Outdoor activities as part of the content of Physical Education, theory or practice? Cultura, Ciencia y Deporte, 11(31), 27-36. doi:10.12800/ccd.v11i31.640.

Pérez-Brunicardi, D., Peire, T., \& Baena-Extremera, A. (2017). Educación física en la naturaleza en España. Panorama y perspectivas. Cuadernos de pedagogía, 479, 44-47.

Prouty, D., Panicucci, J., \& Collinson, R. (2007). Adventure education. Theory and applications. Champaign, IL: Human Kinetics.

Putwain, D. W., Becker, S., Symes, W., \& Pekrum, R. (2018). Reciprocal relations between students'academic enjoyment, boredom, and achievement over time. Learning and Instruction, 54, 73-81. doi:10.1016/j.learninstruc.2017.08.004.

Real Decreto 126/2014, de 28 de febrero, por el que se establece el currículo básico de la Educación Primaria.

Real Decreto 1393/2007, de 29 de octubre, por el que se establece la ordenación de las enseñanzas universitarias oficiales.

Rickinson, M., Hunt, A., Rogers, J., \& Dillon, J. (2012). School Leader and Teacher Insights into Learning Outside the Classroom in Natural Environments. Natural England Commissioned Reports, 97. Retrieved from: http://publications.naturalengland.org.uk/ publication/1989824

Ryan, R. M., \& Deci, E. L. (2000). Self-determination theory and the facilitation of intrinsic motivation, social development, and well-being American Psychology Association, 55(1), 68-78. doi:10.1037/0003066X.55.1.68.

Sáez-Padilla, J. \& Fuentesal, J. (2014). La formación universitaria en actividades físicodeportivas en el medio natural. Situación actual y perspectivas de futuro. Tándem, 45, 14-21.

Sáez-Padilla, J., Rodríguez, J. M., \& Giménez, F. J. (2011). Vision of physical education teachers in secondary education in Andalusia on outdoor activities. Retos, 20, 9-15.

Sáez-Padilla, J., Tornero, I., \& Sierra, A. (2017). Current situation of the teacher training in outdoors activities by physical education teachers. A qualitative study with experts in Andalusia. Espiral. Cuadernos del profesorado, (10)21, 100-117.

Sams, A., \& Bergman, J. (2013). Flip your students' learning. Educational Leadership, 70(6), 16-20.

Santos, M. L., \& Martínez, F. (2011). Aprendizaje integrado de las actividades en el medio natural desde las competencias en la ESO Tándem, 36, 53-60

Tejada, J., \& Saéz-Padilla, J. (2009). Educación Física y Educación Ambiental. Posibilidades educativas de las Actividades en el Medio Natural. Perspectivas de futuro: La educación al aire libre y el aula de naturaleza. Wanceullen, 5, 124-137.

Torres Alberro, C., Robles, J. M, De Marco, S., \& Antino, M. (2017) Analytical Review of the Technology Acceptance Model: Technological Change. Papers: Revista de sociología, 102(1), 5-27. doi:10.5565/rev/ papers.2233.

Trigo-Oroza, C; Navarro-Patón, R.; \& Rodríguez-Fernández, J. E. (2016) Teaching of physical education and in the natural environment. Effect on motivation, basic psychological needs and enjoyment in Primary School children. Trances, 8(6), 487-512.

Whitehead, M. E., Durden-Myers, E. J., \& Pot, N. (2018). The value of fostering physical literacy. Journal of Teaching in Physical Education, 37(3), 252-261. doi:10.1123/jtpe.2018-0139. 